\title{
Growth trends and temperature responses of treeline Norway spruce in the Czech-Polish Sudetes Mountains
}

\author{
Václav Treml ${ }^{1, *}$, Tereza Ponocná ${ }^{1}$, Ulf Büntgen ${ }^{2,3}$ \\ ${ }^{1}$ Department of Physical Geography and Geoecology, Charles University, Faculty of Science, \\ Albertov 6, 12843 Prague, Czech Republic \\ ${ }^{2}$ Swiss Federal Research Institute WSL, Zürcherstrasse 111, 8903 Birmensdorf, Switzerland \\ ${ }^{3}$ Oeschger Centre for Climate Change Research (OCCR), Zähringerstrasse 25, 3012 Bern, Switzerland
}

\begin{abstract}
The Earth's climate system has recently experienced substantial warming, and associated effects are often most pronounced at species-specific distribution limits. Treeline ecotones may therefore be particularly useful to assess the complex interplay of biotic and abiotic factors in relation to environmental change. Here, we present site-dependent growth trends and climate responses of 22 Norway spruce Picea abies (L.) H. Karst. tree-ring chronologies from the treeline ecotone in the Sudetes Mountains (Mts.) along the Czech-Polish border. Annually resolved and absolutely dated ring-width measurements from 2 regions (Giant Mts. and Hrubý Jeseník Mts.), separated by aspect and altitude, resulted in robust chronologies for the 20th century. All sites reveal a close relationship between ring widths and growing season temperatures. The main sitedependent differences in growth trends and temperature responses were attributed to altitude. Trees located at the upper boundary of the treeline ecotone reacted positively to preceding autumn temperatures, and their temperature response was slightly weaker than that of trees from the upper forest limit. Temporal trends in growth-climate responses consisted mainly of a gradual decrease in the influence of preceding October temperatures and an increasing effect of May temperatures towards the present. The proportion of younger trees generally increases upwards within the ecotone, and the most recent growth rates appear unprecedented in a century-long context.
\end{abstract}

KEY WORDS: Czech Republic · Dendrochronology - Norway spruce · Sudetes Mountains · Temperature response $\cdot$ Treeline $\cdot$ Tree rings

\section{INTRODUCTION}

Ongoing climate change likely impacts the diversity and productivity of many ecosystems at various spatiotemporal scales (e.g. Stenseth et al. 2002). Temperature-limited communities close to their distributional margins are especially vulnerable to any alteration of the heat balance, in terms of both longterm temperature trends and their superimposed extremes (Lenoir et al. 2008). The alpine treeline ecotone is among the most prominent temperature- driven ecological phenomena (Körner 2007). This biogeographic boundary relies mainly on decreasing temperature with increasing altitude, characterized by an associated decline in the tree life form, for which both the sink (or growth) limitation and source (photosynthesis, nutrients) limitation hypotheses have been offered as explanations (Körner 1998).

Contemporary responses of treeline trees to climate change may differ due to regional variations in climate and the influence of local (non-altitudinal) factors including topography, competition, frequency 
of disturbances, summit effects, and anthropogenic impacts (Körner 1998, Holtmeier \& Broll 2007, Harsch et al. 2009). One of the most important non-altitudinal treeline drivers is the large, topography-induced variability in near-ground temperatures (Körner 2007). Since the alpine treeline ecotone is especially sensitive to changes in available heat, it may also react to such topography-induced temperature alternations.

Until now, growth-climate response patterns have frequently been studied in high-elevation forest zones, where the formation of tree rings is strongly related to changes in growing season temperature, and the effect of precipitation is generally of secondary order (Fritts 1976). Central European Norway spruce Picea abies (L.) Karst. ring-width chronologies from high-elevation stands have recently been examined for potential relationships with climate over space and time, mainly in the European Alps (Rolland et al. 1998, Frank \& Esper 2005, Büntgen et al. 2006, 2008) and the Western Carpathians (Bednarz et al. 1999, Savva et al. 2006, Büntgen et al. 2007). A few studies have reported that the reactions of trees to individual climatic variables differ along the treeline ecotone, suggesting that the effects of these drivers are influenced by climatic stress intensity (Oberhuber 2004, Vittoz et al. 2008, Leonelli et al. 2009, Moser et al. 2010).

Less attention has been paid to possible growthclimate interactions related to differing slope aspects and stand positions within complex ecotone settings outside the main alpine mountain systems. In fact, the common type of mountains with fully developed forest-tundra ecotones also consists of geologically old (e.g. Hercynian, Caledonian) mountain chains with treelines close to summits on less inclined slopes. The topography-induced microclimate in such mountains often differs from true alpine mountain ranges.

Here, we assessed patterns of spruce growth trends and their climate responses along the alpine treeline ecotone in the Sudetes Mountains (Mts.). Sampling sites were selected based on their aspect (north/south facing) and according to their position in
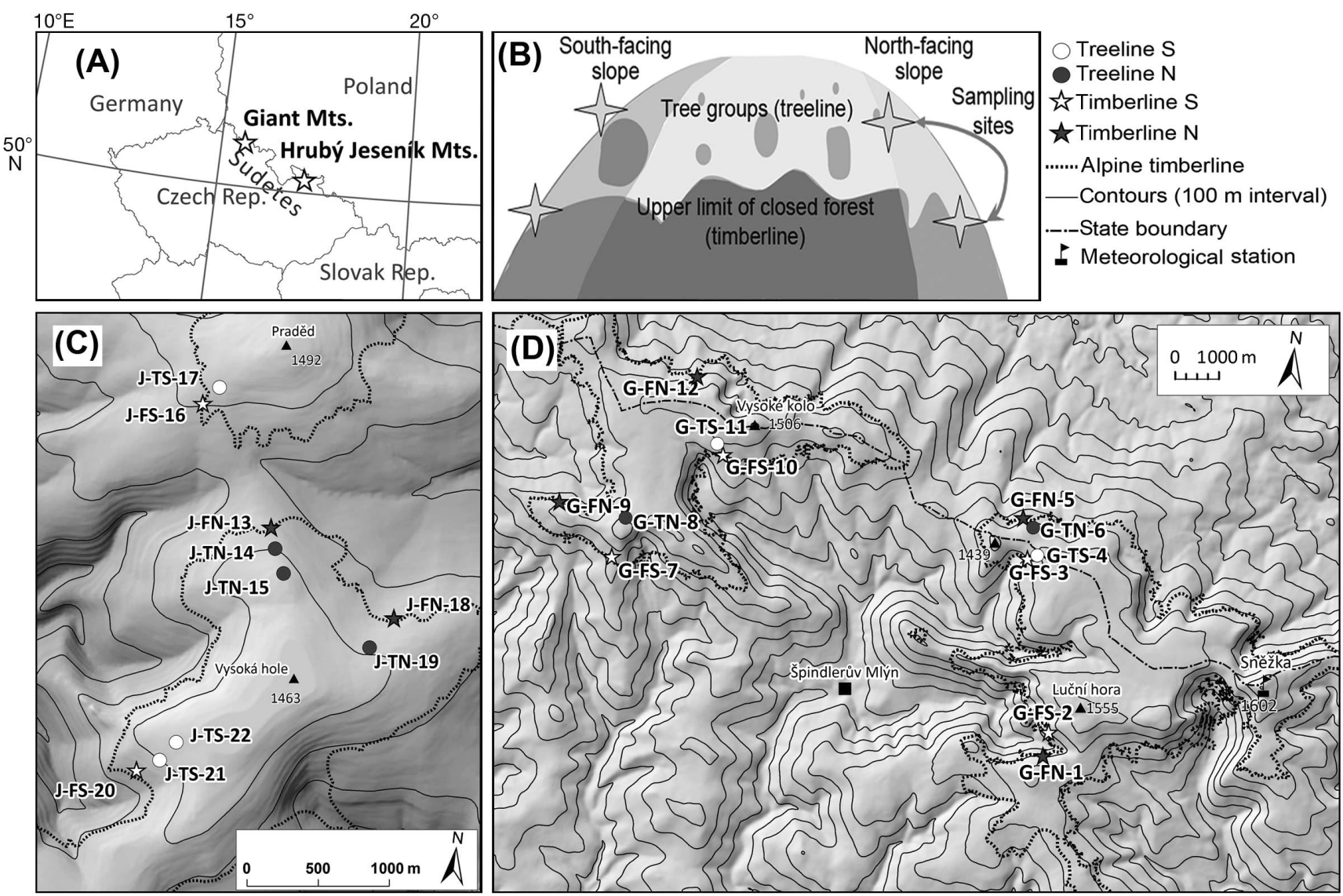

Fig. 1. Geographical position of study areas and sample plots. (A) Study areas in Europe. (B) Configuration of study sites, where shading shows regions of a given slope aspect, timberline, and treeline. (C) Hrubý Jeseník Mountains. (D) Giant Mountains. Site codes are designed as follows: study area (G: Giant Mts., J: Hrubý Jeseník Mts.); site position (T: treeline, F: upper forest limit); aspect (N: north, S: south); site number (1-22) 
either the lower (timberline) or upper (treeline) part of the ecotone between 1260 and $1430 \mathrm{~m}$ a.s.l. We hypothesized that even small, site-dependent differences in microclimate may result in significant differences in growth responses to temperature means, potentially even defining the seasonality of the responses.

\section{MATERIALS AND METHODS}

\subsection{Study area}

The Giant Mts. and Hrubý Jeseník Mts. are the highest parts of the Sudetes mountain chain, which stretches along the Czech and Polish border (Figs. 1 \& 2). Acid crystalline rocks characterize both ranges. Their relief consists of high-elevation, gently sloping surfaces dissected by deep valleys. Several peaks in the Giant Mts. surpass $1500 \mathrm{~m}$ a.s.l., with the highest elevation, Mt. Snezka, reaching $1602 \mathrm{~m}$ a.s.l. The Hrubý Jeseník Mts. are generally lower, with the highest peak being Mt. Praděd (1491 m a.s.l.). Over the period 1961 to 1990, the annual average air temperature near the upper forest limit (1300 m a.s.l.) was $2.1^{\circ} \mathrm{C}$ (Květoň 2001). The study area is characterized by relatively high amounts of total annual precipitation (from 1400 mm in the Hrubý Jeseník Mts. to $1600 \mathrm{~mm}$ in the Giant Mts.), with a significant percentage falling as snow between November and April.

The alpine treeline, with an average altitude of $1290 \mathrm{~m}$ a.s.l. in the Giant Mts. and $1310 \mathrm{~m}$ a.s.l. in the
Hrubý Jeseník Mts., extends from several tens to several hundreds of meters below the summits (Fig. 2), and is influenced by extreme, summit-associated wind conditions. The typical Sudetes treeline ecotone comprises gradually opening spruce stands at the timberline, giving way to clonal clumps of spruce and dwarf pine Pinus mugo Turra above it (Vacek et al. 2011). The height of the spruces at timberline is usually 8 to $9 \mathrm{~m}$, with groups at the highest elevations (1450 to $1500 \mathrm{~m}$ a.s.l.) consisting of trees no higher than $2 \mathrm{~m}$.

The extent of the forest-free area in the Sudetes has been enlarged by anthropogenic deforestation (fires, grazing). This deforestation began in early medieval times, around 1100 yr ago (Novák et al. 2010), and was most intensive during the 18th century. Direct human influence (grazing, hay making, logging), however, drastically decreased around 80 yr ago (Jeník 1961). High-elevation forests in the Sudetes also experienced acid air pollution, which resulted in marked growth depression in the 1970s and 1980s, and was most pronounced in the Giant Mts. (Sander et al. 1995).

\subsection{Sampling strategy and data processing}

Twenty-two sampling plots (Fig. 1 and see Table 1) (12 timberline and 10 treeline sites) were established between 2008 and 2010. Pairwise plots were positioned on north- and south-facing slopes at the same altitude in stands not obviously disturbed by human activities. All study plots were located at the upper
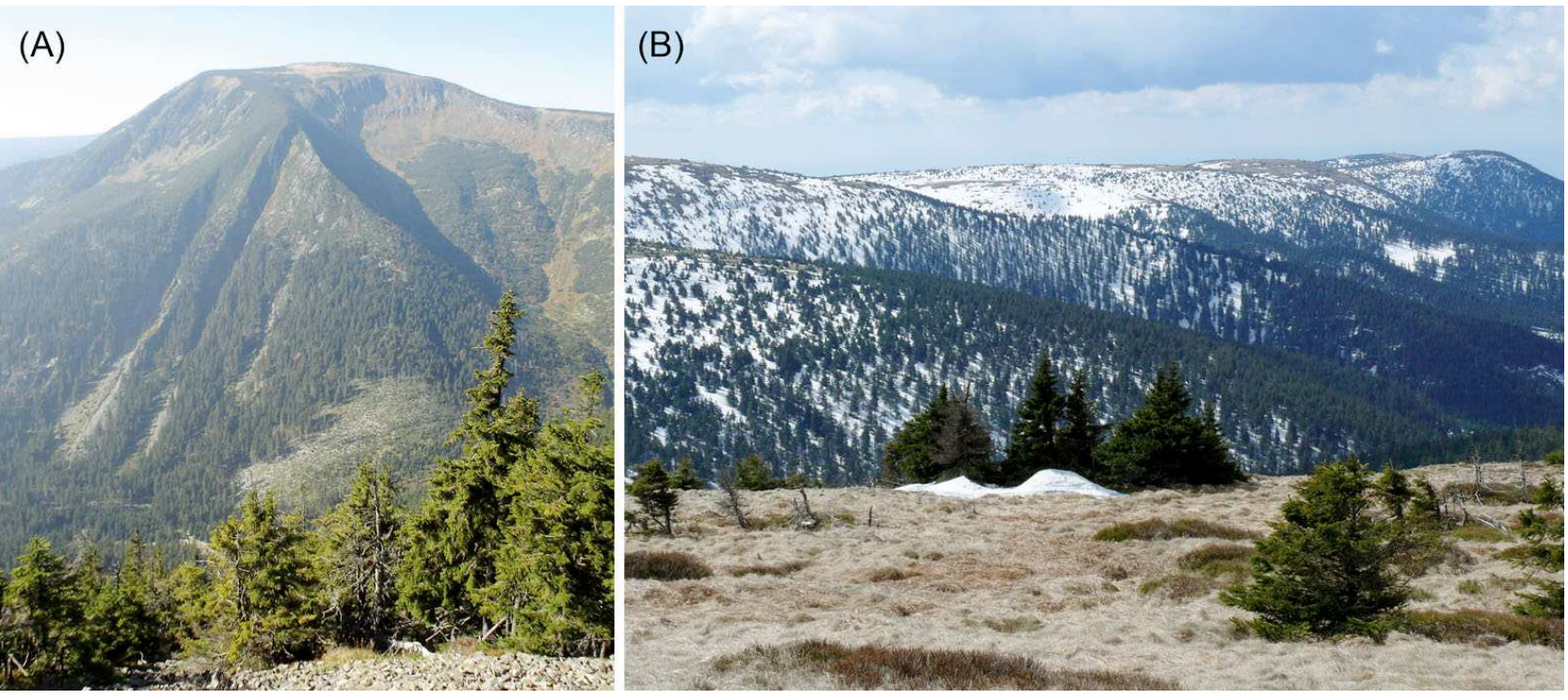

Fig. 2. Views of typical relief and treeline ecotone in the Sudetes. (A) Giant Mts. (B) Hrubý Jeseník Mts. 
reaches of the timberline, mainly within the most elevated quartile of timberlines for the Giant Mts. and Hrubý Jeseník Mts. A total of 18 to 22 dominant and co-dominant spruce trees were sampled at approximately $1 \mathrm{~m}$ stem height in each plot. Two cores per tree were taken to avoid the dominance of compression wood due to slope inclination and wind direction.

Core samples were fixed on wooden supports and sanded, and tree-ring width (TRW) was measured to the nearest $0.01 \mathrm{~mm}$ with a TimeTable measuring device (Vienna Institute for Archaeological Science). For each tree, the mean TRW of both cores was used in subsequent analysis after cross-dating and missing ring identification using PAST 4 software (Knibbe 2004) and COFECHA (Holmes 1983).

Individual series were subjected to standard detrending procedures. In order to suppress heteroscedasticity, data were additionally transformed using adaptive power transformation (Cook \& Peters 1997), after which cubic smoothing splines with $50 \%$ frequency cutoff at $70 \mathrm{yr}$ were fitted to each series (Cook \& Peters 1981). This spline length corresponds to the mean segment length. Site-specific residual chronologies were created using robust means. This method of age trend removal emphasizes interannual to multi-decadal growth fluctuations. Mean sensitivity as a measure of the relative year-to-year variability and Expressed Population Signal (EPS) were computed in order to test for internal signal strength (Wigley et al. 1984).

Hierarchical clustering (Ward's method) based on the common overlapping period (1960 to 2008) assessed coherency among the individual chronologies. Euclidean distance based on the sum of squares was used as a dissimilarity measure. Ward's method joins groups that do not exceed an acceptable level of heterogeneity, thus resulting in clusters that are as homogenous as possible (Ward 1963). Principal component analysis (PCA) was applied for the same overlapping period in order to evaluate the common signal captured in the main directions of variance (i.e. PCA axes; Lepš \& Šmilauer 2003). The relationships of PCA axes to site properties were assessed using $t$ tests, with site PCA loadings as dependent variables, and regional provenance, aspect, and site position within ecotone as grouping variables.

In addition to growth variation, as revealed by indexed TRW chronologies, we also analyzed changes in the absolute growth rates both over calendar time and within each cambial age class. To increase sample sizes for comparison, cores were pooled according to site aspect and position within the ecotone.
Raw TRW was tested for the influences of slope aspect, site position within the ecotone, and region each year either with the $t$-test or the Mann-Whitney $U$-test (MWU), depending on the data distribution. To reduce the effect of multiple testing, confidence levels were adjusted using the Bonferroni correction (Meloun \& Militký 2006).

\subsection{Growth-climate response analysis}

We correlated temperature records against indexed TRW chronologies over their common period of overlap. We also assessed the stability of the growth-temperature relationships over longer periods using moving correlation analysis. Monthly resolved temperature measurements from the Giant Mts. for the years 1881 to 2006 were obtained from the Sněžka meteorological station, located at $1602 \mathrm{~m}$ a.s.l. (Fig. 1). The temperatures recorded by this station represent those of the upland plateau (Głowicki 1997), and the studied sites are within 2 to $12 \mathrm{~km}$ of this station. For the Hrubý Jeseník Mts., climate data were available from Mt. Praděd (1491 m a.s.l.). However, data from this climate station only cover the period 1946 to 1995. Therefore, we used the gridded CRU TS 3.1 dataset (Mitchell \& Jones 2005) which covers the period 1901 to 2009. Correlation coefficients between the CRU TS 3.1 and Praděd station data were higher than 0.95 , with the exception of the monthly temperature means for October $(\mathrm{r}=0.89)$ and November $(r=0.87)$.

Growth-temperature relationships in the period covered by all chronologies were determined using simple correlation analysis (Pearson's correlation coefficients). The significances of correlation coefficients were tested assuming a normal distribution. The monthly and seasonal temperature means of the previous and current years were considered. The resulting site correlation coefficients were finally represented as means of sites grouped according to their position in the treeline ecotone (timberline/treeline), aspect (north/south), and region (Giant Mts./Hrubý Jeseník Mts.).

Correlations were also computed over $21 \mathrm{yr}$ moving windows. Only selected seasonal periods were chosen for moving correlation analysis: the early growing season (May), peak growing season (JuneJuly), and the preceding October. The statistical significance of monotonic decreasing or increasing trends in moving correlation coefficients was tested using the Mann-Kendall test (Hirsch et al. 1991). Standardized $Z$-statistics were used in order to detect 


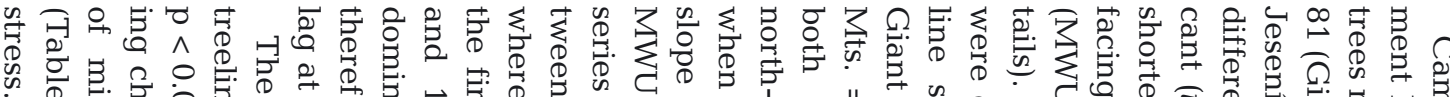

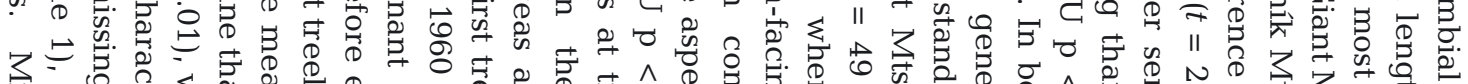

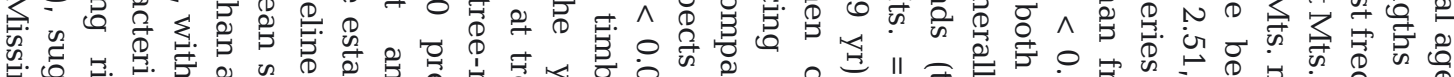

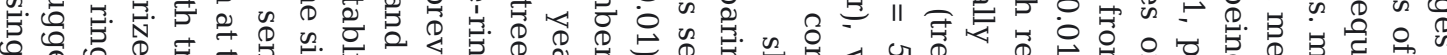

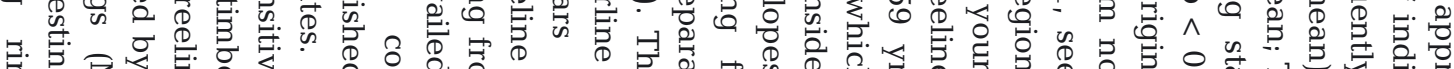

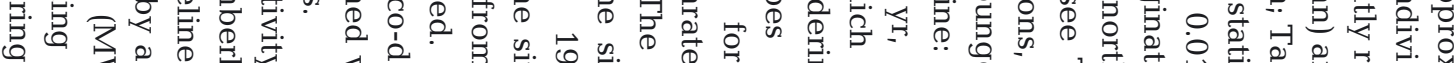

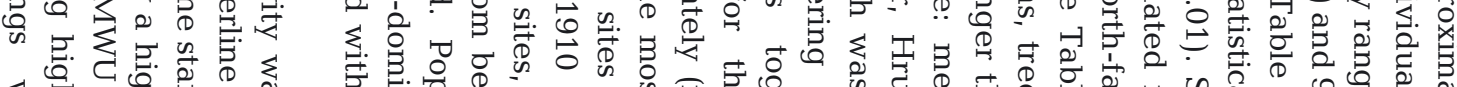

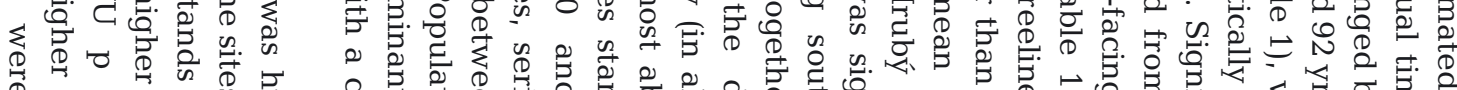
(

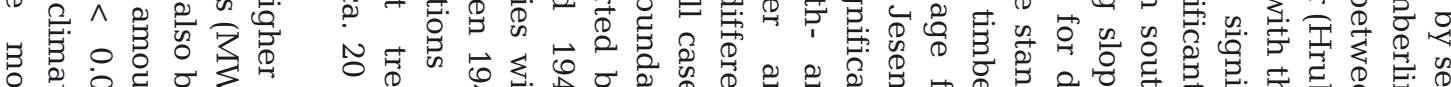

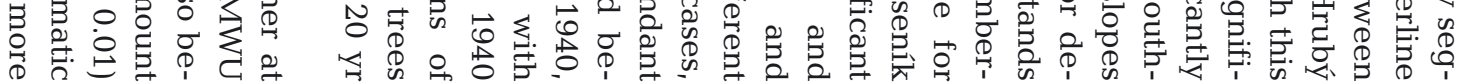
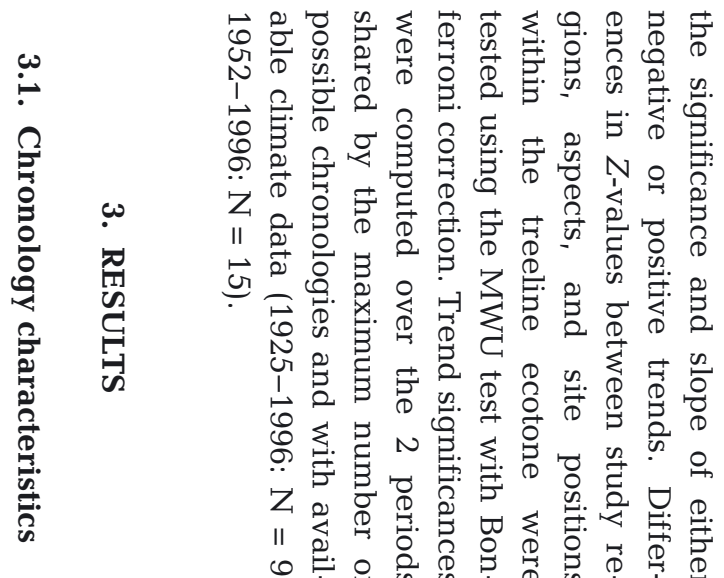

Table 1. Basic characteristics of individual sites and respective tree-ring chronologies. Segment length indicates cambial age of tree. Site codes as in Fig. 1. TRW: tree-ring widthi EPS: Expressed Population Signal

\begin{tabular}{|c|c|c|c|c|c|c|c|c|c|c|c|c|c|}
\hline \multirow{3}{*}{ Site } & \multirow{3}{*}{$\begin{array}{l}\text { Position } \\
\text { along } \\
\text { ecotone }\end{array}$} & \multirow{3}{*}{$\begin{array}{l}\text { Altitude } \\
\text { (m a.s.l.) }\end{array}$} & \multirow{3}{*}{$\begin{array}{l}\text { Slope } \\
\left({ }^{\circ}\right)\end{array}$} & \multirow[t]{3}{*}{ Aspect } & \multirow{3}{*}{$\begin{array}{l}\text { Mean } \\
\text { tree height } \\
\text { (m) }\end{array}$} & \multirow{3}{*}{$\begin{array}{l}\text { No. } \\
\text { of } \\
\text { trees }\end{array}$} & \multirow{3}{*}{$\begin{array}{l}\text { Mean/max. } \\
\text { segment } \\
\text { length }(y r)\end{array}$} & \multirow{3}{*}{$\begin{array}{l}\text { Mean } \\
\text { TRW } \\
(\mathrm{mm})\end{array}$} & \multirow{3}{*}{$\begin{array}{l}\text { Mean no. } \\
\text { of missing } \\
\text { rings tree }\end{array}$} & \multicolumn{2}{|c|}{${ }_{-}$Raw series } & \multirow{2}{*}{\multicolumn{2}{|c|}{$\begin{array}{c}\text { Standardized } \\
\text { chronology }\end{array}$}} \\
\hline & & & & & & & & & & Mean & 1st order & & \\
\hline & & & & & & & & & & sensitivity & $\begin{array}{c}\text { auto- } \\
\text { correlation }\end{array}$ & $\begin{array}{l}\text { Mean } \\
\text { sensitivity }\end{array}$ & EPS \\
\hline G-FS-2 & Timberline & 1300 & 27 & SW & 8.0 & 19 & $48 / 64$ & 2.20 & 0.15 & 0.250 & 0.662 & 0.212 & 0.95 \\
\hline G-FN-1 & Timberline & 1300 & 32 & $\mathrm{~N}$ & 8.5 & 14 & $103 / 129$ & 1.35 & 0.21 & 0.235 & 0.794 & 0.178 & 0.90 \\
\hline G-FS-3 & Timberline & 1320 & 18 & SW & 8.7 & 19 & 81/134 & 1.73 & 0.14 & 0.241 & 0.767 & 0.202 & 0.93 \\
\hline G-FN-5 & Timberline & 1300 & 21 & $\mathrm{~N}$ & 8.5 & 16 & $92 / 142$ & 1.65 & 0.47 & 0.218 & 0.827 & 0.155 & 0.89 \\
\hline G-FS-7 & Timberline & 1260 & 14 & SW & 8.1 & 15 & $69 / 116$ & 1.66 & 0.08 & 0.251 & 0.722 & 0.172 & 0.93 \\
\hline G-FN-9 & Timberline & 1275 & 24 & $\mathrm{~N}$ & 8.5 & 15 & 73/108 & 1.39 & 0.20 & 0.256 & 0.850 & 0.220 & 0.96 \\
\hline G-FS-10 & Timberline & 1310 & 14 & SW & 9.5 & 16 & $92 / 140$ & 1.38 & 0.06 & 0.223 & 0.823 & 0.216 & 0.94 \\
\hline G-FN-12 & Timberline & 1290 & 17 & NW & 8.6 & 14 & $106 / 168$ & 1.12 & 0.42 & 0.220 & 0.856 & 0.158 & 0.87 \\
\hline G-TS-4 & Treeline & 1360 & 13 & SW & 5.6 & 18 & $55 / 82$ & 1.09 & 1.53 & 0.266 & 0.691 & 0.226 & 0.87 \\
\hline G-TN-6 & Treeline & 1360 & 24 & $\mathrm{~N}$ & 5.2 & 15 & $64 / 144$ & 0.68 & 1.28 & 0.303 & 0.731 & 0.184 & 0.86 \\
\hline G-TN-8 & Treeline & 1390 & 15 & $\mathrm{NE}$ & 4.3 & 17 & $44 / 61$ & 1.37 & 1.04 & 0.303 & 0.599 & 0.202 & 0,90 \\
\hline G-TS-11 & Treeline & 1390 & 17 & SW & 4.3 & 15 & $70 / 137$ & 0.98 & 1.60 & 0.266 & 0.800 & 0.178 & 0,89 \\
\hline J-FN-13 & Timberline & 1370 & 17 & $\mathrm{~N}$ & 7.8 & 16 & $88 / 115$ & 1.39 & 0.250 & 0.227 & 0.783 & 0.191 & 0.92 \\
\hline J-FS-20 & Timberline & 1348 & 19 & SW & 7.8 & 16 & $105 / 175$ & 1.45 & 0.187 & 0.228 & 0.758 & 0.164 & 0.92 \\
\hline J-FS-16 & Timberline & 1402 & 13 & $\mathrm{~S}$ & 7.6 & 17 & 95/169 & 1.12 & 0.000 & 0.227 & 0.770 & 0.231 & 0.94 \\
\hline J-FN-18 & Timberline & 1355 & 14 & NE & 7.7 & 18 & $82 / 166$ & 1.28 & 0.056 & 0.218 & 0.760 & 0.206 & 0.94 \\
\hline J-TN-14 & Treeline & 1395 & 14 & $\mathrm{~N}$ & 5.3 & 16 & $57 / 109$ & 1.19 & 0.125 & 0.293 & 0.756 & 0.205 & 0.86 \\
\hline J-TS-21 & Treeline & 1400 & 15 & SW & 5.8 & 17 & $48 / 80$ & 1.35 & 0.172 & 0.263 & 0.701 & 0.192 & 0.90 \\
\hline J-TS-17 & Treeline & 1435 & 12 & $\mathrm{~S}$ & 5.0 & 17 & 49/91 & 1.19 & 0.235 & 0.294 & 0.687 & 0.213 & 0.91 \\
\hline J-TN-19 & Treeline & 1405 & 12 & NE & 6.3 & 16 & $47 / 90$ & 1.64 & 0.125 & 0.235 & 0.594 & 0.171 & 0.91 \\
\hline J-TN-15 & Treeline & 1429 & 14 & $\mathrm{~N}$ & 2.8 & 16 & $45 / 92$ & 0.82 & 0.131 & 0.330 & 0.675 & 0.209 & 0.93 \\
\hline J-TS-22 & Treeline & 1436 & 11 & SW & 3.0 & 15 & $50 / 105$ & 0.78 & 0.735 & 0.361 & 0.669 & 0.229 & 0.91 \\
\hline
\end{tabular}


numerous in the Giant Mts. in comparison with Hrubý Jeseník samples (MWU p < 0.01). First-order autocorrelation was higher at timberline than at treeline stands (MWU $p<0.01$ ), and this difference was more pronounced at Hrubý Jeseník sites. Except for the number of missing rings, no other characteristic of site chronologies was significantly affected by regional provenance or site aspect. EPS of all chronologies exceeded the 0.85 threshold of chronology robustness (Wigley et al. 1984).

As shown in Fig. 3, residual TRW chronologies were relatively similar (first PCA axis explained $68 \%$ of the variance). The second PCA axis explained $12 \%$ of the variance. Differences captured along axis 2 are attributed mainly to those between the 2 regions $(t=14.4, \mathrm{p}<0.01)$. PCA loadings on axis 3 were significantly differentiated by site position (treeline-timberline, $t=2.78, \mathrm{p}=0.01$ ). However, the contribution of the third axis was small, as it explained only $5 \%$ of the overall variance. Aspectrelated differences, if present, were found only at the final level of branching of the dendrogram describing similarity of individual chronologies (Fig. 4).

\subsection{Growth trends}

Growth trends are described using non-indexed TRWs (Fig. 5). This approach is based on averaging ring widths from trees of similar ages. It enabled us to detect site-related temporal trends in TRW without the possible bias caused by indexing. Almost all chronologies shared 1 growth peak from 1940 to 1960 and another after the 1990s, separated by a growth depression in the 1970s and 1980s. The youngest tree rings (age $\leq 20$ ) were highly variable in growth trends, unlike the TRWs of greater cambial age. In all age classes and in both regions, tree rings from timberline stands were significantly wider than those from treeline sites $(t$-tests, $p<0.016)$. Aspectrelated differences in TRW were generally weak, but more pronounced in timberline stands and at higher cambial ages. Significantly wider tree rings (MWU, $p<0.016)$ were found from south-facing than from north-facing timberline stands in $16 \%$ of cases (years) for the $21-40 \mathrm{yr}$ age class, $15 \%$ of the $41-$ $60 \mathrm{yr}$ age class, and $28 \%$ of the $61-80 \mathrm{yr}$ age class. An exception was noted in tree groups of the age class 41-60 yr from the Giant Mts., in which, since 2003, the highest increments were achieved on north-facing slopes. Significant regional differences in TRW were detected in about 13 to $40 \%$ of cases (years) in the case of treeline sites and from 4 to $32 \%$ of cases in timberline stands (t-tests, $\mathrm{p}<0.016$ ). Although in the 1970s and 1980s, TRWs were greater in the Hrubý Jeseník Mts., there was no clear trend for the rest of the study period.

The considerable growth depression in the 1980s was more pronounced at the timberline sites and in the Giant Mts., as shown by the relatively greater reduction in TRW. All age classes have shown significant increases of increments since the 1990s. The maximum TRWs for each of the study sites were achieved at the end of this period (2000 to 2007).
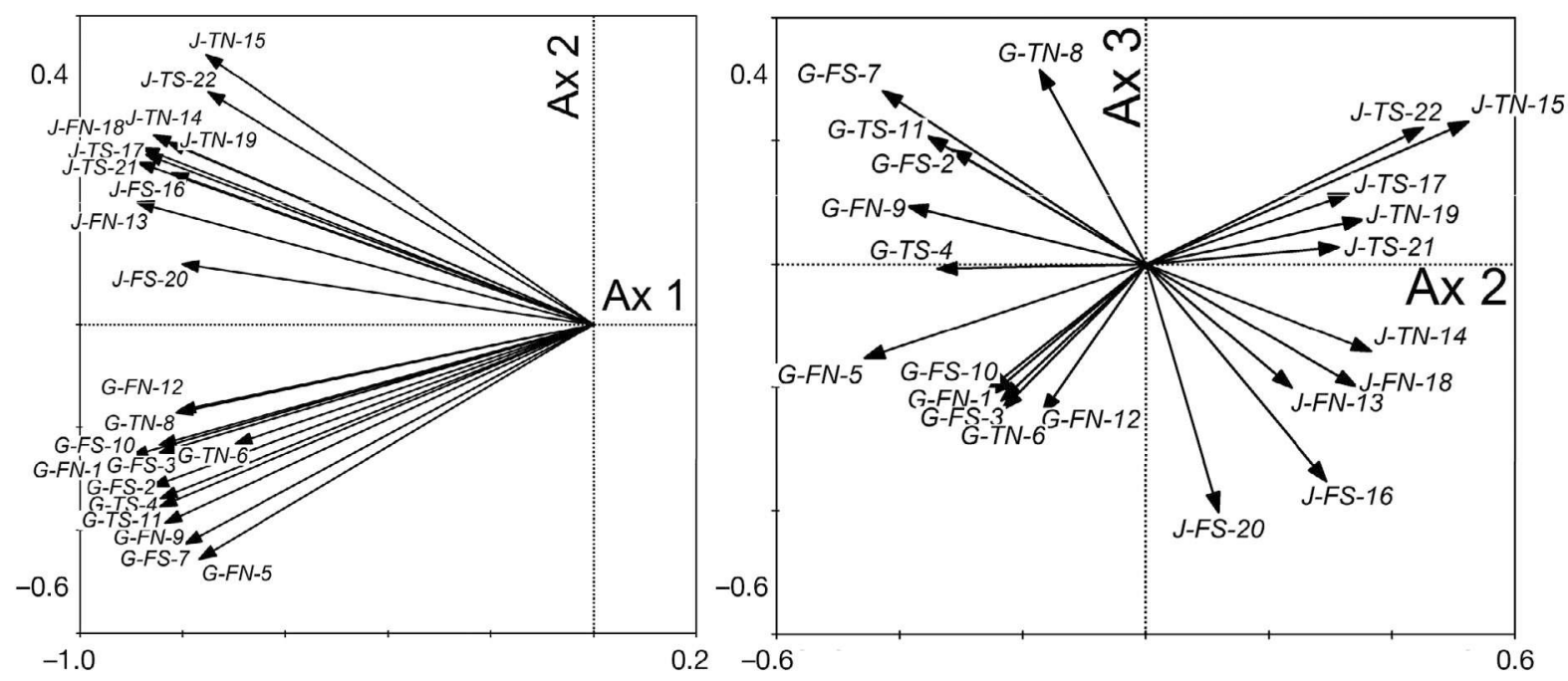

Fig. 3. Picea abies. Principal components (PCA) ordination scheme of Norway spruce tree-ring width (TRW) chronologies based on a common overlap period 1960-2008. (A) Axes 1 and 2, (B) Axes 2 and 3 where axes correspond to individual PCs (e.g. Ax 1 = PC1). Site codes as in Fig. 1 


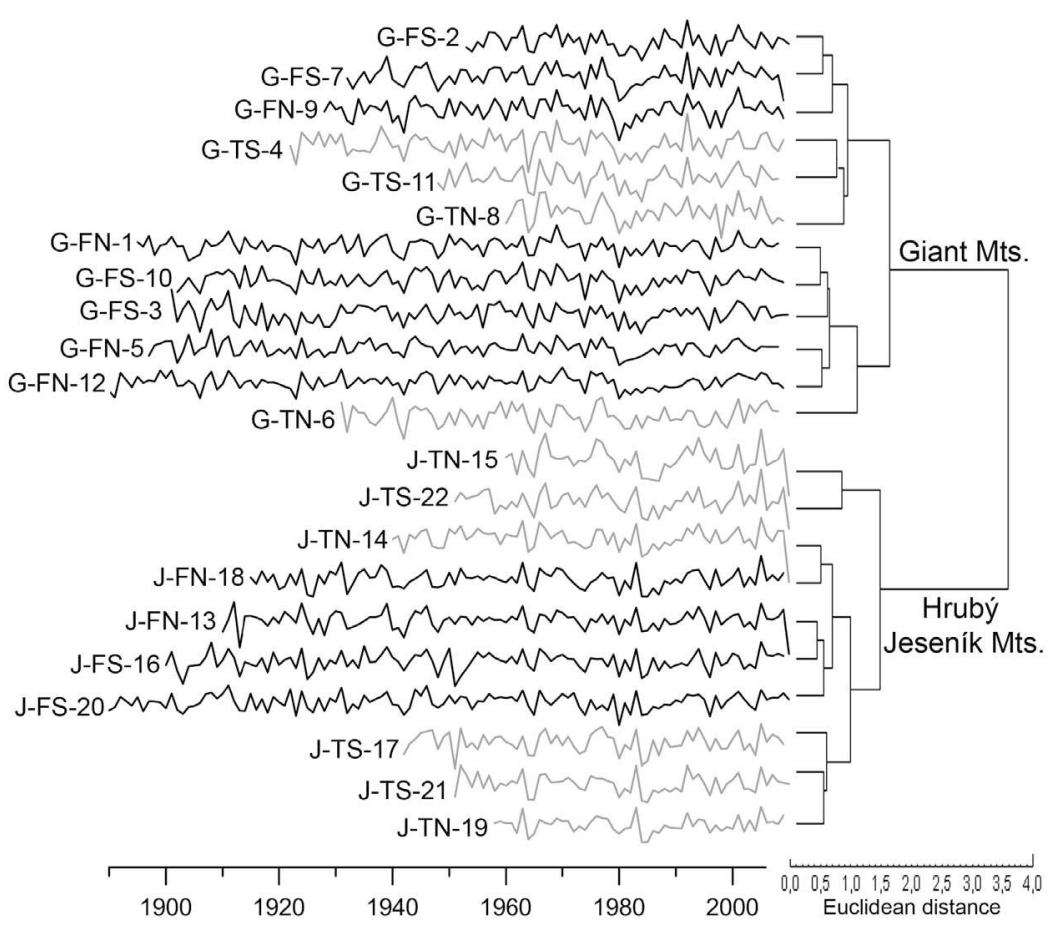

Fig. 4. Picea abies. Residual site chronologies (see Section 2 for more details) of treeline and timberline sites with their similarity indicated by hierarchical cluster analysis. Treeline chronologies are in gray, timberline chronologies in black. Site codes as in Fig. 1
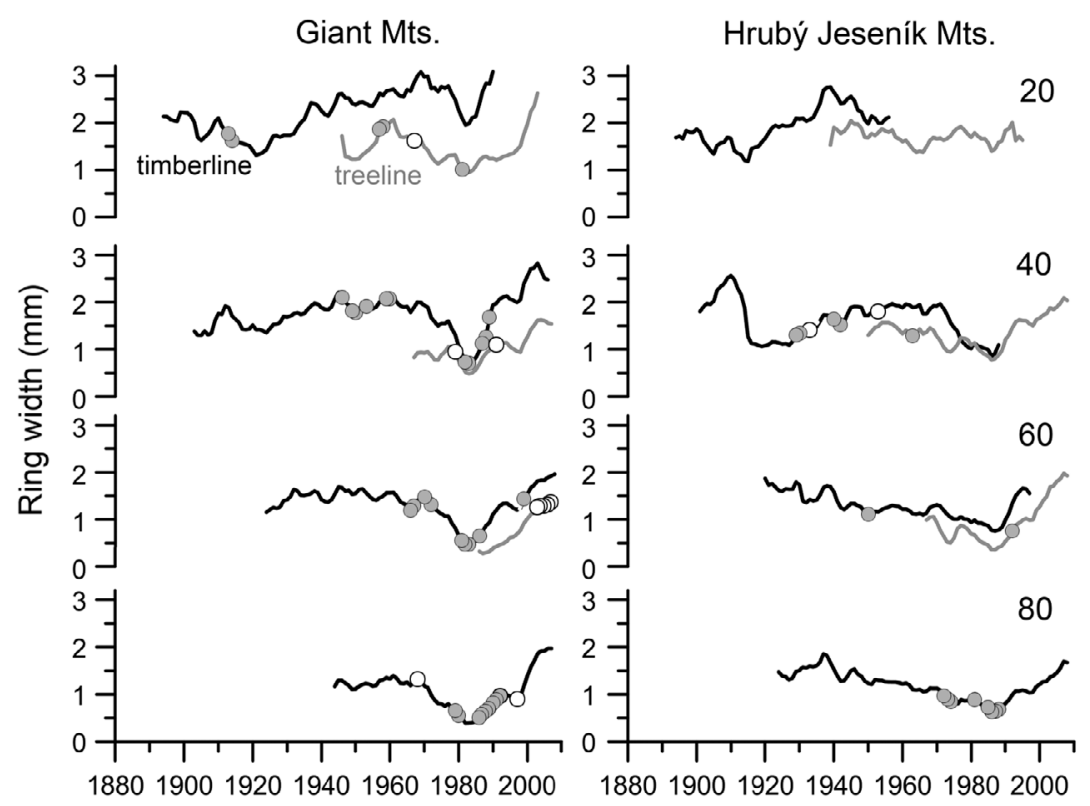

Fig. 5. Picea abies. 5 yr moving means of ring widths for individual age classes (cambial age classes 1-20, 21-40, 41-60 and 61-80 yr; 20, 40, 60, 80 respectively) of Norway spruce in the Giant Mts. and the Hrubý Jeseník Mts. Circles denote significant differences in tree-ring width between differing slope aspects ( $t$-test, $\mathrm{p}<0.016$ after Bonferroni correction). Grey circles: wider tree rings on south-facing slopes; white circles: wider tree rings on north-facing slopes

\subsection{Temperature responses}

In the period shared by all chronologies (1960 to 2006), indexed TRWs from timberline sites were mainly positively correlated with growing season temperatures (individual months May-July, means of May-August, May-July, or June-July; Fig. 6). The correlation coefficients were slightly higher in the Hrubý Jeseník Mts.; their maximum values ranged from 0.41 to 0.48 at Hrubý Jeseník sites and from 0.38 to 0.47 in the Giant Mts. In addition to growing season temperatures, trees in both regions also responded positively to the temperatures of the preceding autumn and negatively to the temperatures of the preceding summer. Although these relations were statistically nonsignificant, they remained consistent among most sites. The effects of aspect on timberline tree reaction to temperatures differed between the regions. Indexed TRWs of trees growing on south-facing slopes in the Hrubý Jeseník Mts. were positively correlated with April temperatures, whereas those in the Giant Mts. revealed positive responses to May temperatures. In the Giant Mts., correlations with the peak growing season (June-August) temperature were stronger on south-facing slopes than on north-facing slopes.

Apart from site G-TN-8 ( $\mathrm{r}=0.46)$, treeline trees were less sensitive to temperatures in both regions (Giant Mts., maximum $\mathrm{r}=0.30-0.36$; Hrubý Jeseník Mts., maximum $\mathrm{r}=0.34-0.44$ ) than those from timberline sites. The overall pattern of temperature response of treeline sites was characterized by a later maximum response, in July. Moreover, correlations with April temperatures were far from significant, and the first month in the growing season that showed a significant positive correlation was May. Unlike those from the Hrubý Jeseník Mts., 3 of the 4 Giant Mts. treeline chronologies showed significant cor- 

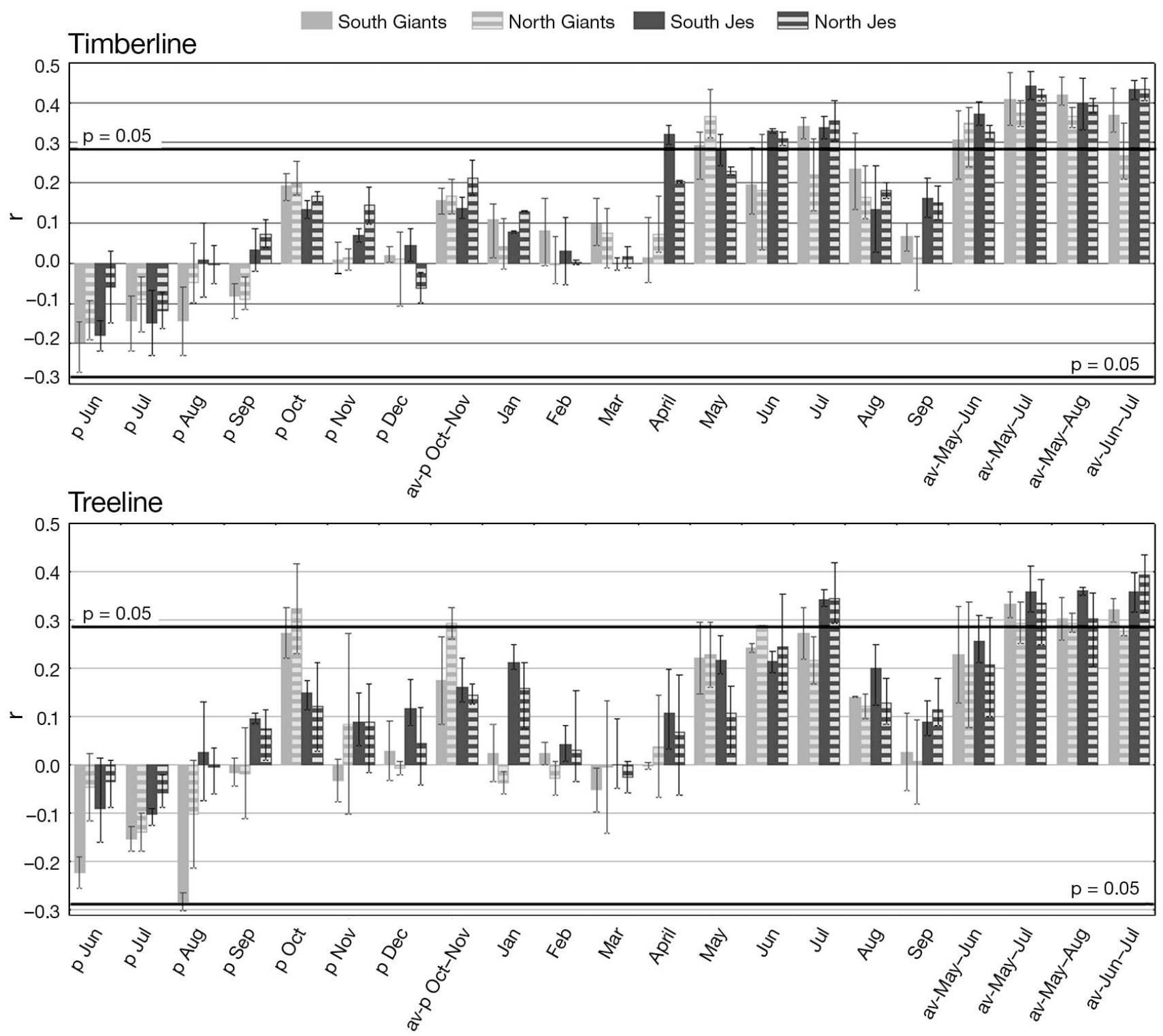

Fig. 6. Picea abies. Pearson correlations between temperature means and corresponding indexed tree-ring widths. Average values (columns), and maximum and minimum values (whiskers) represent all sites grouped according to aspect and region.

Giants: Giant Mts.; Jes: Hrubý Jeseník Mts.; south: South-facing; north: North-facing; av: average; p: previous

relations with preceding autumn temperatures (October or the October-November mean; Fig. 6). Regarding aspect-related temperature-growth differences, both of the south-facing treeline sites in the Giant Mts. exhibited relatively strong negative responses to preceding August temperatures, whereas in the Hrubý Jeseník Mts., south-facing sites reacted positively to May temperatures.

The basic trends in moving correlation coefficients (21 yr window) comprised decreasing sensitivity of TRW to temperatures of the preceding October, and, in contrast, increasing responses to May temperatures (Fig. 7). Correlations with growing season tem- peratures were relatively stable. The decreasing trend of correlations with preceding October temperatures was common to almost all sites (Table 2). Trends in response to May temperatures were not homogenous, because a small number of sites did not react at all. Trends in responses both to May and to preceding October temperatures were not affected by site characteristics (region, altitude, aspect; $t$ tests, $p>0.0016$ ). In contrast, trends in correlations with June-July temperatures were stratified by region ( $t$-test, $\mathrm{p}<0.01)$. While growth sensitivity to peak growing season temperatures slightly increased in the Hrubý Jeseník Mts., the opposite 


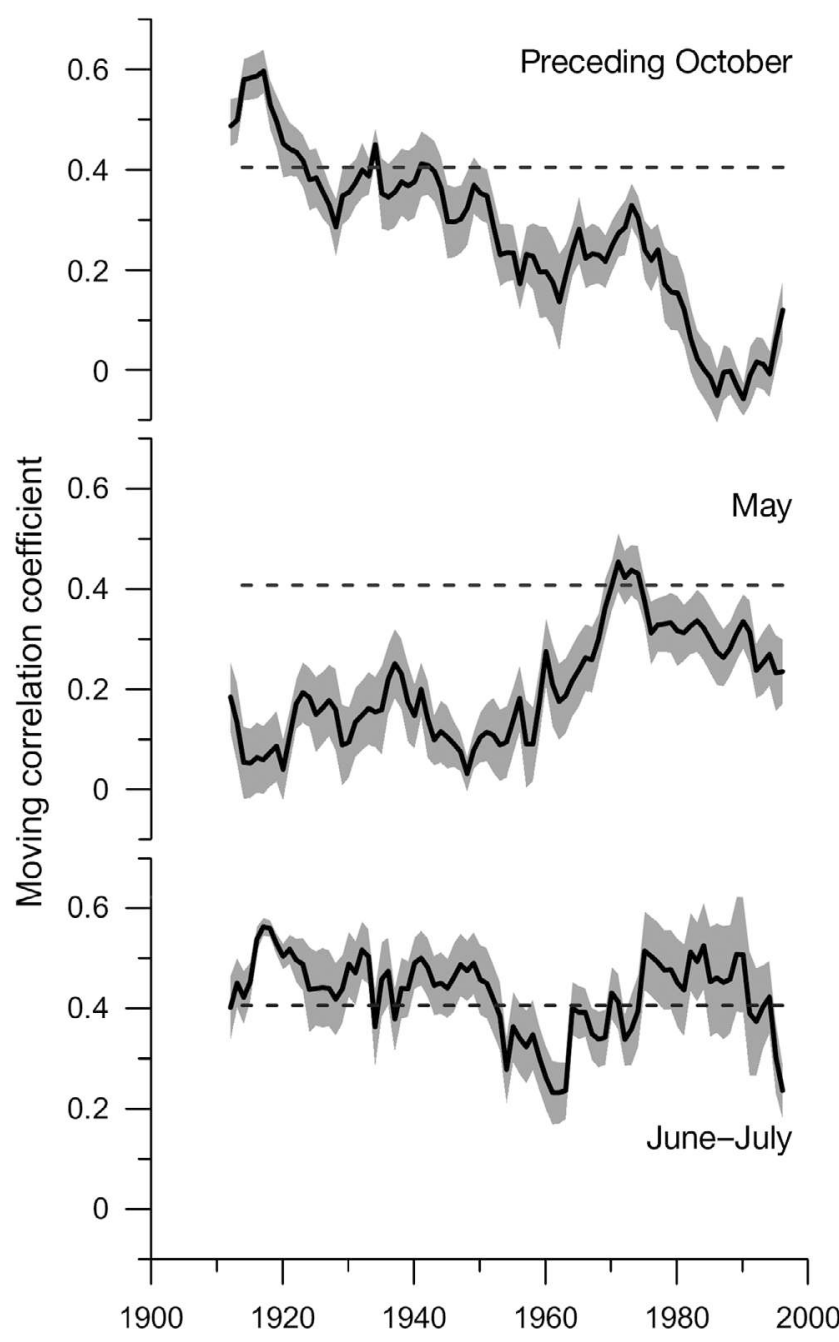

Fig. 7. Picea abies. 21 yr running correlations of tree-ring width indices and selected temperature means for October of the preceding autumn, May, and June-July. Average values (black) with standard deviations (grey) are plotted. Dashed line: $\mathrm{p}=0.05$

trend was evident at the Giant Mts. sites. A significant drop in temperature sensitivity of most stands was detected from 1953-1965 for June-July and preceding October temperatures.

\section{DISCUSSION AND CONCLUSIONS}

\subsection{Growth variability}

Growth-temperature responses were studied at the upper distributional limits of Norway spruce in 2 areas more than $120 \mathrm{~km}$ apart along the Sudetes mountain chain. Despite the large distance between regions, and differences in altitudes and slope
Table 2. Trend analysis for growing season temperaturegrowth correlations. Mann-Kendall $Z$-values and their statistical significances are given: $\mathrm{p}^{*} \leq 0.05,{ }^{* *} \mathrm{p} \leq 0.01,{ }^{* * *} \mathrm{p} \leq$ 0.001. Site codes as in Fig. 1

\begin{tabular}{|c|c|c|c|}
\hline \multirow[t]{2}{*}{ Site } & \multirow[b]{2}{*}{ Preceding Oct } & $Z$-values & \multirow[b]{2}{*}{ June-July } \\
\hline & & May & \\
\hline \multicolumn{4}{|c|}{$1925-1996$} \\
\hline G-FN-1 & $-3.32^{* * *}$ & $5.62^{* * *}$ & $-5.56^{* * *}$ \\
\hline G-FS-3 & $-6.29^{* * *}$ & $4.20^{* * *}$ & $-8.08^{* * *}$ \\
\hline G-FN-5 & $-8.06^{* * *}$ & $5.09^{* * *}$ & $-6.51^{* * *}$ \\
\hline G-FS-10 & $-4.36^{* * *}$ & $7.68^{* * *}$ & -0.53 \\
\hline G-FN-12 & $-3.71^{* * *}$ & 1.71 & $-5.89^{* * *}$ \\
\hline J-FN-13 & $-7.21^{* * *}$ & 1.27 & $6.08^{* * *}$ \\
\hline J-FS-16 & $-7.29^{* * *}$ & $7.58^{* * *}$ & $2.42^{*}$ \\
\hline J-FN-18 & $-7.56^{* * *}$ & $6.17^{* * *}$ & $2.31^{*}$ \\
\hline J-FS-20 & $-6.83^{* * *}$ & $5.46^{* * *}$ & $5.95^{* * *}$ \\
\hline \multicolumn{4}{|c|}{ 1952-1996 } \\
\hline G-FN-1 & $-3.41^{* * *}$ & $5.55^{* * *}$ & $-4.99^{* * *}$ \\
\hline G-FS-3 & $-6.05^{* * *}$ & 1.81 & $-2.63^{* *}$ \\
\hline G-FN-5 & $-6.29^{* * *}$ & $3.90^{* * *}$ & $-6.82^{* * *}$ \\
\hline G-TN-6 & -1.64 & $4.84^{* * *}$ & $-4.74^{* * *}$ \\
\hline G-FS-7 & $-3.88^{* * *}$ & -0.32 & 0.38 \\
\hline G-FN-9 & $-5.91^{* * *}$ & -0.71 & $-2.92^{* *}$ \\
\hline G-FS-10 & $-3.94^{* * *}$ & $2.22^{*}$ & -0.44 \\
\hline G-TS-11 & $-6.09^{* * *}$ & 0.87 & $4.96^{* * *}$ \\
\hline G-FN-12 & $-3.16^{* *}$ & $6.11^{* * *}$ & $-3.81^{* * *}$ \\
\hline J-FN-13 & $-4.53^{* * *}$ & 1.63 & $5.25^{* * *}$ \\
\hline J-TN-14 & $-2.08^{*}$ & $5.17^{* * *}$ & $5.80^{* * *}$ \\
\hline J-FS-16 & $-7.21^{* * *}$ & 1.59 & $2.18^{*}$ \\
\hline J-TS-17 & $-3.22^{* *}$ & $-5.44^{* * *}$ & $6.02^{* * *}$ \\
\hline J-FN-18 & $-2.83^{* *}$ & $3.69^{* * *}$ & $3.92^{* * *}$ \\
\hline J-FS-20 & 0.24 & $2.67^{* *}$ & $4.47^{* * *}$ \\
\hline
\end{tabular}

aspects among sampled stands, the resulting indexed TRW chronologies shared almost $68 \%$ of their total variance. This common variance among sites represents growth reactions to macroclimatic conditions. The remaining part of the variance was driven mainly by regional-scale effects $(12 \%)$ and by site position (elevation) within the alpine treeline ecotone $(5 \%)$. The least pronounced differences were attributable to site aspect (north/south). In other mountain systems, regional provenance has been shown to have the strongest clustering effect (Carrer et al. 2007). Oberhuber (2004) also reported a stronger effect of site altitude than site aspect from treeline ecotones in the inner Austrian Alps. Thus, even small altitudinal differences seem to consistently have greater effects than differing slope aspects on tree growth along the treeline ecotone. Raw TRWs revealed a similar pattern of spatial variation. In both the Giant Mts. and the Hrubý Jeseník Mts., they mainly followed altitudinal gradients along the alpine treeline ecotones, with no definite tendency in 
TRW differences related to site aspect. Weak exposure effects within the high-elevation locations could be related to strong winds preventing heating of air near the ground and therefore eliminating the advantage of south-facing slopes (Treml \& Banaš 2008).

We found that tree growth in the treeline ecotone of the Sudetes Mts. is governed by growing season temperatures, similarly to other high-elevation sites (Fritts 1976). In our study, the May-July temperatures drove radial growth with the greatest effect. Correlation coefficients found for the relationship between site chronologies and seasonal temperature means were similar to those from other temperaturelimited sites in the Alps (Frank \& Esper 2005, Büntgen et al. 2008) and Tatras (Savva et al. 2006, Büntgen et al. 2007), but were higher than those from nearby ranges below the timberline (Wilson \& Hopfmueller 2001, Rybníček et al. 2009). According to a large-scale European comparison (Mäkinen et al. 2003), Norway spruce growing within the range of June-July temperatures of 8 to $10^{\circ} \mathrm{C}$, as in our study, should display correlation coefficients in the 0.3 to 0.6 range, and our data support this.

However, even within the relatively narrow zone of the treeline ecotone, some differences in growthtemperature responses were due to site elevation. Specifically, at treeline sites, the responses to preceding autumn temperatures were consistently stronger, although this effect was often not statistically significant. Treeline trees are especially stressed due to loss of carbon from snow/ice abrasion and winter desiccation (Tranquillini 1979). In order to cope with winter losses, they require the longest possible growing season for maturation of needles, shoots, and buds and sufficient carbon storage (Oberhuber 2004). Compared to timberline stands, the growth response of treeline trees to mean monthly temperatures for the spring and for the peak growing season was delayed as a consequence of the later onset of the growing season.

We expected that treeline trees would display overall higher temperature sensitivity than timberline trees since they grow in a colder environment (Körner 1998). Chronologies derived from treeline trees reflected higher mean sensitivity, and treeline trees also had significantly thinner annual increments, along with a higher proportion of missing rings. All of these characteristics result from extreme climatic stress, but as shown by the lower correlation coefficients, the relationship of treeline chronologies to temperature means was weaker than that between timberline chronologies and monthly temperatures. This could be ascribed to treeline sites having a high proportion of young trees, as these are very sensitive to competition and environmental stressors (e.g. wind, snow redistribution, temperature extremes), which are largely not reflected in temperature means. Typically, growth-temperature relationships of juvenile trees are weaker even after removing the age effect (Carrer \& Urbinati 2004). Additionally, treeline trees are more exposed to strong winds and rime, resulting in frequent damage to apical meristems, in which the hormones regulating radial growth are produced (Pallardy \& Kozlowski 2008). As a consequence, non-temperature-driven TRW reductions occur. Similarly, in some other studies (Vittoz et al. 2008, Gruber et al. 2009), correlations were less significant for treeline than for timberline trees, and a less significant growth-temperature response has also been reported for wind-exposed stands (Oberhuber 2004). The majority of studies, including our own, thus show that in most cases, there is no gradient of increasing growth-temperature sensitivity with increasing elevation along the alpine treeline ecotone.

Aspect-related variations in growth-temperature responses were not homogenous across the 2 regions. Although in the Giant Mts. the north-facing timberline sites exhibited higher positive correlations with May temperatures when compared to south-facing sites, in the Hrubý Jeseník Mts. the south-facing timberline sites had higher positive correlations with April temperatures compared to northfacing slopes. This was probably related to regional differences in temperature and snow coverage. In the Hrubý Jeseník Mts., spring temperatures at timberline elevations are milder and snow pack depth is generally less (Květoň 2001, Migala 2005). This facilitates an overall earlier onset of the growing season on south-facing slopes in the Hrubý Jeseník Mts. However, in May, when the growing season generally begins at most locations throughout the Giant Mts. and Hrubý Jeseník Mts., the onset of radial growth depends on snow thawing, especially, in the case of the Giant Mts., on north-facing timberline sites. Based on our results as well as data from other mountain regions (Villalba et al. 1994, Kirchhefer 2001, Oberhuber 2004, Leonelli et al. 2009), aspectinduced variations in growth-temperature relationships are probably of greater ecological importance in those regions that are characterized by large altitudinal gradients, at high latitudes or in more continental areas than in the relatively wet and windy Sudetes Mts.

Interpreting relations between temperature means and growth rates also requires taking precipitation 
totals into account, because precipitation significantly affects growth of treeline trees in some mountain areas (e.g. Oberhuber et al. 2008, Saulnier et al. 2011). Therefore, we also analyzed the dependence of TRW on precipitation sums (not shown), but found only the precipitation sum of the previous growing season and March to have a consistent (but not statistically significant) effect at most sites (correlation coefficients ranging from 0.18 to 0.27 ). However, the effect of previous growing season precipitation might to some extent be a statistical artifact, since high summer precipitation implies low temperatures, and TRW indices are negatively correlated with preceding growing season temperatures (see Fig. 6). Moreover, the most extreme droughts (in 1947, 1976, and 2003, listed in Brázdil et al. 2009) in the Czech Republic were not reflected in our chronologies at all, with the most pronounced growth reductions related exclusively to negative temperature anomalies (in 1923, 1942, and 1974). Hence, we assume that treeline ecotone stands reflect a temperature signal alone, unlike stands in lower-elevation, montane forests of the Sudetes Mts. and nearby mountain chains that show mixed effects of precipitation and temperature (Sander et al. 1995, Kroupová 2001).

\subsection{Treeline trends}

At least in some regions, climatic signals captured in TRW variations across alpine treeline ecotones are thought to have changed during the last century (Wilson \& Elling 2004, Büntgen et al. 2006, Carrer \& Urbinati 2006, D'Arrigo et al. 2008). In our study in the Sudetes Mts., we identified distinct trends of decreasing growth sensitivity to preceding October temperatures and increasing sensitivity to May temperatures. The first trend probably resulted from an increase in growing season temperatures providing sufficient accumulation of carbon storage prior to October. The second has also been reported from the southern Italian Alpine arc (Carrer \& Urbinati 2006) and has been related to an overall extension of the growing season in Europe (Menzel \& Fabian 1999), in line with growing season changes observed in the Sudetes Mts. (Dubicka \& Glowicki 2000). Sensitivity to peak growing season temperatures (June-July) has remained relatively stable in the Sudetes over the last century. However, we found that in the second half of the 20th century, the sensitivity increased in the Hrubý Jeseník Mts., probably due to the increasing proportion of older trees in the sampled stands. We did not find this in the chronologies from the Giant Mts., possibly because of pollution stress (Kroupová 2002). The drop in sensitivity to June-July and to preceding October temperatures recorded in the 1950s and 1960s is probably attributable to high proportions of juvenile trees at treeline sites, which probably had weaker reactions to temperatures.

Although we did not specifically focus on the age distribution of sampled trees, it is evident that most of the dominant trees emerged during the 20th century. This tendency was even more pronounced at treeline sites, in line with independent reports from other parts of the Hrubý Jeseník Mts. (Šenfeldr \& Maděra 2011). Most treeline stands were established during the 1940s to $1960 \mathrm{~s}$, with the first culmination of radial increments dating to this period. The highest ring widths were achieved both at timberline and treeline sites at the end of the 1990s and from 2001 to 2010. This observation coincides with evidence from many mountain sites across central Europe (Rolland et al. 1998, Paulsen et al. 2000, Büntgen et al. 2007, 2008, 2010, Vittoz et al. 2008). Current growth rates of treeline sites in the Sudetes Mts. equal those of timberline sites during the 1960s and 1970s, which may illustrate pressure for an upward shift of the treeline ecotone. Throughout the whole study region, growth depressions in the 1970s and 1980s were followed by a period of intense growth recovery. All age classes of trees reached their highest ring width values during the last decade. This pattern, together with the predominance of juvenile specimens in treeline stands and trends in growth-temperature seasonality, indicates a strong upward shift of the treeline ecotone.

Acknowledgements. This study was funded by grant project GACR P504/11/P557. T.P. was supported by grant GAUK $264911 / 2011$. We are grateful to the authorities of the Krkonoše/Karkonosze national park Jeseníky protected area for technical support and for permission to conduct research in protected areas. We thank J. Rosenthal for improving the English.

\section{LITERATURE CITED}

Bednarz Z, Jaroszewicz B, Ptak J, Szwagrzyk J (1999) Dendrochronology of Norway spruce (Picea abies (L.) Karst.) in the Babia Gora National Park, Poland. Dendrochronologia 16:45-55

Brázdil R, Trnka M, Dobrovolný P, Chromá K, Hlavinka P, Žalud Z (2008) Variability of droughts in the Czech Republic, 1881-2006. Theor Appl Clim 97:297-315

> Büntgen U, Frank DC, Schmidhalter M, Neuwirth B, Seifert M, Esper J (2006) Growth/climate response shift in a long subalpine spruce chronology. Trees 20:99-110

Büntgen U, Frank DC, Kaczka R, Verstege A, ZwijackKozica T, Esper J (2007) Growth responses to climate in a 
multi-species tree-ring network in the Western Carpathian Tatra Mountains, Poland and Slovakia. Tree Physiol 27:689-702

Büntgen U, Frank DC, Wilson R, Carrer M, Urbinati C, Esper $\mathrm{J}$ (2008) Testing for tree-ring divergence in the European Alps. Glob Change Biol 14:2443-2453

Büntgen U, Frank D, Trouet V, Esper J (2010) Diverse climate sensitivity of Mediterranean tree-ring width and density. Trees 24:261-273

Carrer M, Urbinati C (2004) Age-dependent tree-ring growth responses to climate in Larix decidua and Pinus cembra. Ecology 85:730-740

> Carrer M, Urbinati C (2006) Long-term changes in the sensitivity of tree-ring growth to climate forcing in Larix decidua. New Phytol 170:861-871

Carrer M, Nola P, Eduard JL, Motta R, Urbinati C (2007) Regional variability of climate-growth relationships in Pinus cembra high elevation forests in the Alps. J Ecol 95:1072-1083

Cook ER, Peters K (1981) The smoothing spline: a new approach to standardizing forest interior tree-ring width series for dendroclimatic studies. Tree-Ring Bull 41: 45-53

Cook ER, Peters K (1997) Calculating unbiased tree-ring indices for the study of climatic and environmental change. Holocene 7:361-370

D'Arrigo R, Wilson R, Liepert B, Cherubini P (2008) On the 'divergence problem' in northern forests: a review of the tree-ring evidence and possible causes. Global Planet Change 60:289-305

Dubicka M, Głowicki B (2000) A long-term view on the ecoclimate of the Karkonosze Mountains in the light of complex indices. Opera Corcontica 37:55-61 (in Polish with English abstract)

Frank D, Esper J (2005) Characterization and climate response patterns of a high-elevation, multi-species treering network for the European Alps. Dendrochronologia 22:107-121

Fritts HC (1976) Tree rings and climate. Academic Press, New York, NY

Głowicki B (1997) Long-term temperature record of Snezka station. In: Sarosiek J, Stursa J (eds) Geoekologiczne problemy Karkonoszy I. Acarus, Poznań, p 117-123 (in Polish with English abstract)

Gruber A, Baumgartner D, Zimmermann J, Oberhuber W (2009) Temporal dynamic of wood formation in Pinus cembra along the alpine treeline ecotone and the effect of climate variables. Trees 23:623-635

Harsch MA, Hulme PE, McGlone MS, Duncan R (2009) Are treelines advancing? A global meta-analysis of treeline response to climate warming. Ecol Lett 12:1040-1049

Hirsch RM, Alexander RB, Smith RA (1991) Selection of methods for the detection and estimation of trends in water quality. Water Resour Res 27:803-814

Holmes RL (1983) Computer-assisted quality control in tree ring dating and measurement. Tree-Ring Bull 43:69-78

Holtmeier FK, Broll G (2007) Treeline advance - driving processes and adverse factors. Landsc Online 1:1-33

Jeník J (1961) Alpine plant communities of the Giant Mts., Králický Sněžník Mts., and Hrubý Jeseník Mts. Theory of anemo-orographic systems. Nakladatelství ČSAV, Prague (in Czech with English summary)

Kirchhefer AJ (2001) The influence of slope aspect on radial increment of Pinus sylvestris L. in northern Norway and its implications for climate reconstruction. Dendro- chronologia 18:27-40

Knibbe B (2004) Personal analysis system for tree-ring research 4 - Instruction manual. SCIEM, Vienna

Körner C (1998) A re-assessment of high elevation treeline positions and their explanation. Oecologia 115:445-459

Körner C (2007) Climatic treelines: conventions, global patterns, causes. Erdkunde 61:316-324

Kroupová M (2001) Dendrochronology of Norway spruce results from ICP Forests permanent plots. In: Boháčová L, Uhlírová H, Lomský B (eds) Monitoring zdravotního stavu lesa v České republice. Ročenka programu ICP Forests 2001. Výzkumný ústav lesního hospodářství a myslivosti Jíloviště-Strnady. VULHM, Prague, p 78-85 (in Czech with English abstract)

Kroupová M (2002) Dendroecological study of spruce growth in regions under long-term air pollution load. J For Sci 48:536-548

Květoň V (2001) Climatological normals of air temperature of the Czech Republic in the period 1961-1990 and selected air temperature characteristics of the period 1961-2000. Czech Hydrometeorological Institute, Prague

Lenoir J, Gégout JC, Marquet PA, de Ruffray P, Grosse H (2008) A significant upward shift in plant species optimum elevation during the 20th century. Science 320: 1768-1771

Leonelli G, Pelfini M, Battipaglia G, Cherubini P (2009) Siteaspect influence on climate sensitivity over time of a high-altitude Pinus cembra tree-ring network. Clim Change 96:185-201

Lepš J, Šmilauer P (2003) Multivariate analysis of ecological data using CANOCO. Cambridge University Press, Cambridge

Mäkinen H, Nöjd P, Kahle HP, Neumann U and others (2003) Large-scale climatic variability and radial increment variation of Picea abies (L.) Karst. in central and northern Europe. Trees (Berl) 17:173-184

Meloun M, Militký J (2006) Kompendium statistického zpracování dat, metody a řešené úlohy včetně CD. Academia Praha, Prague

> Menzel A, Fabian P (1999) Growing season extended in Europe. Nature 397:659

Migala K (2005) Climatic belts in the European mountains and the issue of global changes. Stud Geograf 78:1-149 (in Polish with English summary)

> Mitchell TD, Jones RG (2005) An improved method of constructing a database of monthly climate observations and associated high-resolution grids. Int $\mathrm{J}$ Climatol 25: 693-712

Moser L, Fonti P, Büntgen U, Franzen J, Esper J, Luterbacher J, Frank D (2010) Timing and duration of European larch growing season along altitudinal gradients in the Swiss Alps. Tree Physiol 30:225-233

> Novák J, Petr L, Treml V (2010) Late-Holocene humaninduced changes to the extent of alpine areas in the East Sudetes, Central Europe. Holocene 20:895-905

Oberhuber W (2004) Influence of climate on radial growth of Pinus cembra within the alpine timberline ecotone. Tree Physiol 24:291-301

Oberhuber W, Kofler W, Pfeifer K, Seeber A, Gruber A, Wieser G (2008) Long-term changes in tree-ring climate relationships at Mt. Patscherkofel (Tyrol, Austria) since the mid-1980s. Trees 22:31-40

Pallardy SG, Kozlowski TT (2008) Physiology of woody plants. Academic Press, London

Paulsen J, Weber UM, Körner C (2000) Tree growth near 
treeline: abrupt or gradual reduction with altitude? Arct Antarct Alp Res 32:14-20

Rolland C, Petitcolas V, Michalet R (1998) Changes in radial tree growth for Picea abies, Larix decidua, Pinus cembra and Pinus uncinata near the alpine timberline since 1750. Trees 13:40-53

Rybníček M, Čermák P, Kolář T, Přemyslovská E, Žid T (2009) Influence of temperatures and precipitation on radial increment of Orlické hory Mts. spruce stands at altitudes over $800 \mathrm{~m}$ a.s.l. J For Sci 55:257-263

Sander C, Eckstein D, Kyncl J, Dobrý J (1995) The growth of spruce (Picea abies (L) Karst) in the Krkonoše-(Giant) Mountains as indicated by ring width and wood density. Ann For Sci 52:401-410

Saulnier M, Edouard JL, Corona C, Guibal F (2011) Climate/growth relationships in a Pinus cembra high-elevation network in the Southern French Alps. Ann For Sci 68:189-200

Savva Y, Oleksyn J, Reich PB, Tjoelker MG, Vaganov EA, Modrzynski J (2006) Interannual growth response of Norway spruce to climate along an altitudinal gradient in the Tatra Mountains, Poland. Trees 20:735-746

Šenfeldr M, Maděra P (2011) Population structure and reproductive strategy of Norway spruce (Picea abies L. Karst) above the former pastoral timberline in the Hrubý Jeseník Mountains, Czech Republic. Mt Res Dev 31: 131-143

Stenseth NC, Mysterud A, Ottersen G, Hurrell JW, Chan K, Lima M (2002) Ecological effects of climate fluctuations. Science 297:1292-1296

Tranquillini W (1979) Physiological ecology of the alpine

Editorial responsibility: Nils Chr. Stenseth, Oslo, Norway timberline. Tree existence at high altitudes with special reference to the European Alps. Springer Verlag, Berlin

Treml V, Banaš M (2008) The effect of exposure on alpine treeline position: a case study from the High Sudetes, Czech Republic. Arct Antarct Alp Res 40:751-760

Vacek S, Hejcmanová P, Hejcman M (2011) Vegetative reproduction of Picea abies by artificial layering at the ecotone of the alpine timberline in the Giant (Krkonoše) Mountains, Czech Republic. For Ecol Manag 263:199-207

$>$ Villalba R, Veblen T, Ogden J (1994) Climatic influences on the growth of subalpine trees in the Colorado Front Range. Ecology 75:1450-1462

Vittoz P, Rulence B, Freléchoux F (2008) Effects of climate and land-use change on the establishment and growth of cembran pine (Pinus cembra L.) over the altitudinal treeline ecotone in the central Swiss Alps. Arct Antarct Alp Res 40:225-232

> Ward JH (1963) Hierarchical grouping to optimize an objective function. J Am Stat Assoc 58:236-244

> Wigley TML, Briffa KR, Jones PD (1984) On the average value of correlated time series, with applications in dendroclimatology and hydrometeorology. J Clim Appl Meteorol 23:201-213

Wilson R, Elling W (2004) Temporal instabilities of treegrowth/climate response in the lower Bavarian Forest region: implications for dendroclimatic reconstruction. Trees 18:19-28

Wilson RJS, Hopfmueller M (2001) Dendrochronological investigations of Norway spruce along an elevational transect in the Bavarian Forest, Germany. Dendrochronologia 19:67-79

Submitted: February 6, 2012; Accepted: June 29, 2012

Proofs received from author(s): November 8, 2012 